\title{
Law Is the Command of the Sovereign: H. L. A. Hart Reconsidered
}

\begin{abstract}
ANDREW STUMPFF MORRISON*
Abstract. This article presents a critical reevaluation of the thesis-closely associated with H. L. A. Hart, and central to the views of most recent legal philosophers-that the idea of state coercion is not logically essential to the definition of law. The author argues that even laws governing contracts must ultimately be understood as "commands of the sovereign, backed by force." This follows in part from recognition that the "sovereign," defined rigorously, at the highest level of abstraction, is that person or entity identified by reference to game theory and the philosophical idea of "convention" as the source of signals with which the subject population has become effectively locked, as a group, into conformity.
\end{abstract}

\section{Introduction}

Few recent legal philosophers regard a "command" of the state, backed by force, as an accurate or even a helpful characterization of a law. The view that power-coercion-is irrelevant to defining "what law is" has held a dominant position ${ }^{1}$ in Anglo-American legal jurisprudence for over fifty years.

This settled viewpoint would surely startle many people in the street, who if you surprised them with the question "What is law?" might be expected to respond somewhat along the lines of: "It's a thing where if you do X or don't do Y, the police will throw you in jail." The force-is-irrelevant conclusion would also have startled every legal philosopher in history through the middle of the nineteenth century, and many through the first part of the twentieth. But academic orthodoxy it has been; and the idea has served, furthermore, as the necessary effective starting point for a number of increasingly attenuated (though highly charged)

\footnotetext{
* I wish to thank Amy Kuras, Simon Blackburn, Brian Tamanaha, Martin Osborne, Robert Axelrod, Robert J. Aumann, James Fearon, Mark Schwimmer, Theodore St. Antoine, Howard Bromberg, Richard D. Friedman, and Sonja Starr, as well as anonymous reviewers on behalf of Ratio Juris, for comments on an earlier draft (with all or part of which some of the foregoing vehemently disagreed), and Seth Quidachay-Swan and Danny Lawder of the University of Michigan Law Library, for research assistance. I am also grateful to Frederick Schauer for permitting me to review an advance draft of his book The Force of Law (Schauer 2015).

${ }^{1}$ The degree of consensus is striking. See, e.g., Christie 1968, 650 n. 6, and sources cited therein; Schauer 2010a, 1-2.
} 
philosophical debates, controversies, and theses, of which the emergent consequences over the last fifty years have been-in the law schools, if nowhere elseremarkable.

More recently the stirrings of partial reassessment have begun to manifest themselves. Writers such as Ekow Yankah and, especially, Frederick Schauer, have questioned whether legal philosophy's complete dismissal of coercion can really be justified, suggesting among other things that even if it is not an essential definitional condition of law, nonetheless, because all the legal systems of which we are aware actually do involve state coercion, coercion certainly seems at least highly relevant for jurisprudence.

I contend that these challenges to the prevailing view are too weak; that in fact state coercion is necessary as a matter of definition to the concept of law; and that the arguments to the contrary-today associated most closely with H. L. A. Hartthat have formed the basis of most recent legal philosophy have, from the start, been logically and foundationally unsound.

\section{Commands Backed by Force}

The following briefly recites some of the background required to appreciate how we came to be where we are. For a more complete historical recounting the reader is directed to Chapter 2 of Professor Schauer's recent book, The Force of Law (Schauer 2015).

The idea that a law is not a "command backed by force" - that such an assertion is hopelessly crude and antiquated ${ }^{2}$ — dates back at least to the late 1800 s (see Schauer 2015, 25), having gathered momentum in subsequent decades (e.g., Hägerström 1953, 34; Pound 1945, 415-6). It reached hegemonic status, however, with the postwar writings of Herbert Lionel Adolphus Hart of the University of Oxford, perhaps the most prominent legal philosopher of the last half of the last century.

Hart rejected the views of earlier philosophers such as Jeremy Bentham and John Austin. Writing in the 1770s, Bentham had been concerned to bring clarity to the mist-enshrouded world of natural law and arbitrary taxonomy that had descended from the Middle Ages to William Blackstone, Bentham's conventionally authoritative contemporary. Bentham argued that no one can be under a legal obligation without the threat of punishment. Indeed that threat is, he said, what constitutes "obligation" - and therefore wrong is synonymous with punishable (Bentham 1977, 182-6, 184). Furthermore, Bentham (ibid., 260) declared that to be "authoritative" a decree must come from the sovereign. Fifty years later, Austin sought more carefully and exhaustively to enumerate essentially the same point of view as Bentham's. Austin $(1885,346-7)$ said "Every law is a direct or circuitous command"; and "every command imposes an obligation." What does it mean for a person to be under an "obligation"? It means, said Austin (ibid., 452-4, 510), to be "liable to the evil of a sanction which he wants to avoid. This is what is meant by obligation [...]. A sanction is a conditional evil [...] which he will incur if he violates the obligation." Moreover "[e]ither directly or remotely, the sovereign, or supreme legislator, is the author of all law, and all laws are derived from the same source."

2 "Command theories of law and legal obligation have passed from sophisticated jurisprudence" (Postema 2001, 495). 
There it was: Law is a form of command, direct or indirect, from a sovereign to its subjects, backed by the "threat of evil." According to Austin all laws can be understood this way, even laws that do not seem to take the form of commands. "Rights," for example, are to be understood as a subset of this same overall scheme: To say someone has a "legal right" is to say the sovereign has commanded everyone else to permit that right to be exercised (ibid., 344, 355).

Thus l'ancien régime of legal philosophy, which seems to have predominated, not without challenge, for something over 100 years, until around the time Hart found himself in full-throated disagreement with all these views of things. Although various writers had by then questioned whether "coercion" ${ }^{3}$ was really an essential element of "law," Hart's restatement, extension, and promotion of these arguments were regarded by his peers as having settled the matter once and for all.

If the reader will forbear an extended quotation, we can summarize all the essence of Hart's quarrel with "the command theory" in his own words: ${ }^{4}$

[T] the quintessence of morals, seems breathtaking in its simplicity and quite inadequate. There is much, even in the simplest legal system, that is distorted if presented as a command [...].

The situation which the simple trilogy of command, sanction, and sovereign avails to describe, if you take these notions at all precisely, is like that of a gunman saying to his victim, "Give me your money or your life." The only difference is that in the case of a legal system the gunman says it to a large number of people who are accustomed to the racket and habitually surrender to it. Law surely is not the gunman situation writ large, and legal order is surely not to be thus simply identified with compulsion.

This scheme, despite the points of obvious analogy between a statute and a command, omits some of the most characteristic elements of law. Let me cite a few. It is wrong to think of a legislature (and a fortiori an electorate) with a changing membership, as a group of persons habitually obeyed [...]. Even if we waive this point, nothing which legislatures do makes law unless they comply with fundamental accepted rules specifying the essential lawmaking procedures [...]. These fundamental accepted rules specifying what the legislature must do to legislate are not commands [...].

Other critics dimly sensed a further and more important defect in the command theory [...]. This more radical defect is as follows. The picture that the command theory draws of life under law is essentially a simple relationship of the commander to the commanded [...]. In this picture no place, or only an accidental or subordinate place, is afforded for a distinction between types of legal rules which are in fact radically different. Some laws require men to act in certain ways or to abstain from acting whether they wish to or not. The criminal law consists largely of rules of this sort [...]. But other legal rules are presented to society in quite different ways and have quite different functions [...]. Such are the rules enabling individuals to make contracts, wills, and trusts, and generally to mould their legal relations with others. Such rules, unlike the criminal law, are not factors designed to obstruct wishes and choices of an antisocial sort. On the contrary, these rules provide facilities for the realization of wishes and choices. They do not say (like commands) "do this whether you wish it or not," but rather "if you wish to do this, here is the way to do it."

3 This paper will not address the deeper meaning of coercion itself, a topic explored by Austin (ibid., 453-7), and more recently by Nozick (1969), Edmundson (1995), Anderson (2010), and many others. See Schauer 2015, chap. 9, and the notes thereto. For present purposes it suffices to accept (as Edmundson, for example, seemingly would not; but Hart and others would) that "coercion" includes the threat of penalties commonly associated with criminal law, such as physical arrest and imprisonment.

4 These excerpts are from an article published in 1957 (Hart 1957, 603-4). The same arguments appear at greater length in Chapters 2-4 of Hart's later book The Concept of Law (Hart 1961). 
The dominance within later jurisprudence of this reasoning can hardly be overstated. Recently, as noted above, examples have begun to appear of observers willing to challenge, if not the argument itself, at least the idea that coercion is entirely irrelevant to, and can be ignored in analyzing, the concept of law. This marks a change from the previously nearly uncontested orthodoxy, in which the usual approach was to take coercion's irrelevance as a given; as a starting point, which required little further discussion post-Hart. ${ }^{5}$

Some of the more recent observers are concerned with issues that are not the immediate subject of this paper. While accepting as given Hart's view that coercion is not definitionally necessary to law, they nonetheless argue coercion might still be relevant, for other reasons-perhaps because the coercion that seems so often to be associated with law requires justification. ${ }^{6}$ Some implications of this paper for those arguments are mentioned briefly in Section 5 below, but the focus here is on the starting assumption-logically prior to these species of discussion-that coercion is definitionally irrelevant.

The idea that Hart's view of coercion's definitional superfluity was just wrong on its face does not seem to have been entertained. Ekow Yankah and Frederick Schauer have come closest, but both accept much or most of Hart's position.

Schauer's views require special attention. He has been among the first, and easily the most persistent and prominent, of those challenging the dismissal of coercion as relevant to law, having now added to previous papers (Schauer 2010a,b) a book specifically devoted to the subject (Schauer 2015). He has drawn pointed attention to the extent to which legal philosophers' definitions of law have diverged from those of everyone else, and has carefully marshalled evidence undercutting a pillar of Hart's and others' views: that people commonly obey law not from the threat of coercion but because they feel some internal obligation to obey law, qua law (Schauer 2010b; 2015, 37). He deserves credit for a great many insights, and perhaps above all for tenacity, in raising the lonely question whether the column might be marching in somewhat the wrong direction.

But Schauer ultimately accepts Hart's most basic assertion. Schauer's argument is only that coercion seems to be, in the world in which we live, empirically important, and therefore it is misguided for legal philosophers to ignore it. He concedes "the fact that coercion is not a necessary property of law, in the sense that there can be, and sometimes is, law without coercion" (ibid.). ${ }^{7}$ Coercion is important, to be sure: Schauer analogizes coercion as a property of "law" to the capacity to fly as a property of "birds." Not all birds fly, so flight is not a definitional requisite to

${ }^{5}$ A complete list of those accepting the irrelevance of coercion would be lengthy. A sampling can be found at Schauer 2015, 171 n. 3, including references to work of Leslie Green, John Gardner, Jules Coleman, and others. For a recent, approving recapitulation of Hart's argument, see Shapiro 2011, 59-78.

${ }^{6}$ See, for example, Lamond 2001, 44, 56: Although "all known legal systems have been coercive," the explanation "is not that coercion is necessary to account for the efficacy of law, but rather that the right to regulate coercion lies within the scope of the law's distinctive claim to authority." In roughly similar vein is the work of Raz (e.g., Raz 2009), Ripstein (2004), and Hughes (2013). Priel (2008) has challenged Hart, while focusing on Hart's conclusions about the "internal perspective" on law. See Section 5 below.

7 Among many similar statements in the book: "In equating law with coercion-the threat of punishment or some other 'evil'-Austin was simply wrong"' (Schauer 2015, 167). 
being a bird the way having feathers and a backbone are (Schauer 2010b, 613-4; $2015,37-41)$, but flight is a vital part of the "central case" of the category comprising birds. Just so:

And thus if coercive law is the dominant instantiation of law as it is experienced, the fact that some law, even some important law, is noncoercive should be recognized but should not distort an inquiry into the nature of the social phenomenon that is law. That Bentham and Austin may have overstated the case for coercion is no excuse for facilitating an even great[er] misunderstanding and inaccuracy by understating it. (Schauer 2015, 40-1)

Yankah $(2008,1214)$ seems to have gone further, in positing that "coercion is inherent to the very nature of the law." Yet Yankah also accepts Hart's idea that "large portions of the law exist without sanctions" (ibid., 1215), including the law of contracts and wills. He defends these contrasting positions by distinguishing the ideas of "coercion" and "sanction," and seems to suggest coercion is present even in the case of laws like those of contracts and wills, where he says sanctions are not.

Schauer and Yankah were wrong in my view to have made their concessions. Sanction-based state coercion is to the definition of law what possession of feathers, not capacity for flight, is to the definition of birds in Schauer's example. The problem with the thesis that has dominated legal philosophy for several generations is not, I think, one of emphasis but of fundamental inaccuracy.

\section{The Flaws in the Argument}

Let us treat separately with what are effectively two categorical problems Hart (in the excerpt above) believed he and others had identified with viewing law as "the command of the sovereign." The first is: Who is the "sovereign" who issues commands-for example, in the case of a constitutional democracy like the United States? If laws comprising the United States Code are to be thought of as "commands" "to the population," then what person, or even group of persons, could be said to be issuing these commands, right now, to the citizens who must obey them? Furthermore, who could be said to be commanding Congress, or the Supreme Court, to follow the Constitution? The second, "more radical defect" is: Many laws, such as those governing contracts and wills, do not take the form of commands.

The first of these objections by Hart is in fact less trivial than the "more radical" second, so it will be more convenient to take them in reverse order.

Thus, the different categories of law: Certainly, Hart conceded, a criminal law might be conceived as a "command." But laws governing contracts and wills are different, he said; they are not commands, but rather "enabling rules," which "provide facilities for the realization of wishes and choices." ${ }^{8}$

The distinction Hart was trying to draw is logically void. What Austin and Bentham had said was that laws-all laws - can be characterized as conditional commands; and the law of contract is no exception: The sovereign says: If one of my subjects makes a promise to another, and if the form of the promise meets certain formal (and perhaps also substantive) requirements, then I, the sovereign, command-what? It is true the sovereign does not, perhaps, command the promisor to

${ }^{8}$ Schauer $(2015,2)$ echoes this language, agreeing with "Hart's seemingly sound observation that law often empowers rather than coerces." 
keep her promise (although in the case of specific performance the sovereign does indeed so command). But the sovereign does command something, and that is: If the statutorily prescribed promise has been made, and the promisor fails to perform, and the promisee brings suit, I, the sovereign, command the promisor to pay the promisee some form of damages, most likely money. If the promisor does not pay then I command the sheriff to seize the promisor's property to satisfy that judgment. If the promisor resists the sheriff then I command the sheriff, with the help of as many armed officers as may be necessary, physically to arrest and handcuff the promisor and lock the promisor in a jail cell.

The laws of contract-and of wills-are conditional commands. They specify a set of conditions, and further specify, if those conditions are met, an order to do something: an order backed by the force of the state. As for the gunman analogy that Hart found decisively inapt, all that is required is to imagine the gunman's having a henchman, and the lead gunman's saying to the henchman within the prisoners' hearing: "If one of our prisoners, Prisoner A, promises to share her water bottle with Prisoner B, and Prisoner A reneges on that promise; then shoot Prisoner A." The law of contract is effectively a command, a conditional command, backed by the "threat of evil"; and the distinction between law and the order of a gunman must be sought elsewhere.

Hart seemed to recognize potential objections like these, but thought them sophistry:

Much ingenuity has gone into the task of reducing laws of this second sort [that is, laws like those governing contracts and wills] to some complex variant of laws of the first sort [criminal laws] [...]. Yet to urge this is really just to exhibit dogmatic determination to suppress one aspect of the legal system in order to maintain the theory that the stipulation of a sanction, like Austin's command, represents the quintessence of law. (Hart 1957, 605)

One might point to these sentences and others like them ${ }^{9}$ as agents responsible for discouraging reconsideration of Hart's theories for the last half-century. Who wants to be thought dogmatic? But the reduction of wills and contracts to coercive commands-though possibly (slightly) "complex"-is not dogmatic; it is not sophistry. It is not the product of obsession by Austin with the command theory. Recourse to the force of the state is the point of contract law: It is the reason I comply with forms of contract. I do so so that if the other party does not comply I can invoke the full force of the state in order to coerce her compliance. ${ }^{10}$

The analysis of wills-another example that Schauer $(2015,30)$ and Yankah $(2008$, 1215), like Hart, find persuasive-is the same. The reason a testator complies with the statutory forms of the will is to prevent, by the force of the state, any competing claimant from taking her property. Also to similar effect: the statutory prescriptions

\footnotetext{
9 See also Hart 1961, 49. Similarly, see Schauer 2010a, 5: “It is true that even [contract] laws can be reduced to hypothetical imperatives, in which citizens are told what they must do once they have decided to enter into a contract, but such a reduction seems convoluted, missing the distinction between what the citizen simply must or must not do, on the one hand, and how the law structures and enforces the range of citizen choice, on the other." As phrased, that distinction also eludes this author.

${ }^{10}$ There is a reason people incur the cost of hiring lawyers to draft and review contracts. They want them to be "enforceable," to choose a word.
} 
for creating a corporation (or any other legally defined entity, such as a trust), which Schauer again agrees with Hart cannot be regarded as commands. To create a corporation by complying with statutory forms is to satisfy conditions to application of an array of standing, state-enforceable commands directed at persons in specific relations to each other; and that, again, is the point of creating a corporation. ${ }^{11}$

All these writers ${ }^{12}$ seem to have been brought up short at a law's label. If a rule is not labeled a criminal law-and not expressed on its face in the form of a command-it is not under this analysis a command. The categorical names "criminal law" and "contract law," however, are for this purpose artificial. ${ }^{13}$ Nor is it persuasive to dismiss contractual requirements as "fragments" of commands. That the sovereign may not have placed all the enforcement and other contract-law provisions in the same place in the statute books-which is not something that distinguishes contract from criminal law-does not detract from the rules' overall net logical effect. The conditionality of contract-law commands also does not differentiate them from criminal-law commands. If I have invited you into my house, you do not commit criminal trespass by entering; if I have not, you do.

Although Austin had expressed the notion of law as a conditional command, Hart concentrated his criticism on another, less persuasive, idea: that contract law could be brought within the command model by asserting that violation of contract law requirements would meet with the "sanction of nullity" (Hart 1961, 33-5). That is: Austin (as recounted by Hart) argued the sovereign could be viewed as having issued a command to comply with the required forms of contract, backed by the "threat," if the forms were not satisfied, of treating the contract as nonexistent. That idea concededly seems less than completely coherent. ${ }^{14}$ The sovereign "commands" nothing of the sort, and treating an agreement as a nullity does not fall within reasonable usage of "coercion by force." If contractual forms are not satisfied-or, even if they are, if an aggrieved party does not bring suit-the sovereign simply does not involve itself in the matter. Hart's, and later Schauer's and others', views of the conditional-command argument, which is not weak, appear to have been effectively occluded by the "sanction of nullity" argument, which is. ${ }^{15}$

11 "Creating a corporation" is linguistic shorthand for satisfying necessary conditions to a set of definite legal effects, all of which can be rephrased as conditional commands. Schauer (2015, 110-23) also makes much of laws that reward behavior as examples of noncoercive laws. That would be right only if the sovereign were an individual person and the reward were to be drawn from the sovereign's personal assets. In every other case (that is, every legal case), such a law is ultimately a coercion-backed conditional command to allocate assets away from one or more owners to another.

12 And many others, including Roscoe Pound. See Schauer 2015, 24-5.

13 As Bentham showed, "there is no such thing as a law that is civil and not penal, nor one that is penal and not civil" (Bentham 1945, 33; ed. paraphr. of ibid. 53-6). Bentham is regarded by modern legal scholars as unsophisticated (note 2 above), but the situation is really reversed.

${ }^{14}$ It is also less than clear that Austin meant to make this argument. He used the phrase "sanctioned by nullities" (Austin 1995, 457) once, in passing, not specifically in the context of discussing contract law. See Kramer 2013, 110-1, for discussion of Austin's use of the phrase and Hart's treatment of it. In the version of this argument Hart constructed and attacked, the "command" and "sanction" in question would have to be understood as directed at the aggrieved party to a breached contract, rather than at the breaching party.

15 See Schauer 2015, 26-9, for extended discussion of the "sanction of nullity"; but his book does not address the conditional command possibility. 
Hart $(1961,35-8)$ also wondered whether what Austin conceived was a command from the sovereign to a court, to enforce the contract. To the contrary, the command in Austin's conditional sense is ultimately, in Austin's conception, directed to the party whose compliance is sought; a command that may be accomplished through a chain of intervening commands to subordinate officials and courts (as, likewise, may be a criminal law). The "problem" of accounting for delegated commands through multiple layers of officials is another issue with the command theory that Hart found generally intractable, for no evident reason. ${ }^{16}$

As for Hart's above-excerpted assertion, finally, that contract laws "do not say (like commands) 'do this whether you wish it or not,' but rather 'if you wish to do this, here is the way to do it'" (Hart 1957, 604; emphasis added): It is challenging to discern what might have been meant by this statement. Surely not that two parties are prohibited, if they so choose, from writing an agreement that does not comply with the requirements for a binding contract? Or, alternatively, that the statutory forms are a nonbinding recommendation; or that if you do not comply with the specified forms you should be ashamed of yourself? None of these is right. The significance of complying with the statutorily prescribed form is-entirely, only-that if either party then wishes to rely on the coercive power of the state in case the other party reneges, she may do so; and that is because the sovereign has effectively issued a command, backed by force, and the form of that command is this:

If you enter into an agreement that meets the prescribed requirements of a contract, you must honor the agreement or pay damages.

Now to Hart's less obviously misplaced objection, that the "orders backed by force" model cannot explain who is doing the commanding. If the situation of the gunman is not distinguishable from the situation of law in its description of the nature of what is happening - as it is not-it must be distinguished on the basis of the identity of the actors. Austin said a command is law if it comes from "the sovereign." That is what distinguishes law from the command of a gunman.

But, objected Hart, how could the rules governing legislatures, for example, in a democracy like the United States, be so described? Those rules are a command, as of this moment, from whom? If the legislators hew to a Constitution, who is "commanding" them to do so? The Supreme Court? Then who is commanding the Supreme Court to apply the Constitution to the legislature, or the legislature to obey the Court's interpretations? Perhaps the command theory might explain the case of a monarchy, but who is the "sovereign" in a democracy? If it is something like the "common will," the problematic implication is that each of us is to be understood as constantly taking orders from and giving orders to everyone else. As to statutes: How can we say they are commands, personally, of legislators, even acting as a group? Axel Hägerström had already pointed out that cannot be right: What if the legislators, while in their respective homes and not "in session," for example, unambiguously publish their unanimous direction that $\mathrm{X}$ be done? That is a "command," by all of them, but it is not a "law" and will not be treated as such (Hägerström 1953, 35).

16 See note 31 below. 
Though less facially wrong than "contract laws are not commands," this argument is nonetheless just as wrong. What is required is a more realistic apprehension of the dynamics of sovereignty, in any form. The first essential point is that at a level of sufficient abstraction there is no difference between democracy and a monarchy or dictatorship in understanding the application of physical power to and among a group.

Imagine, for example, that you are one among several nobles in a royal court. The king happens to be unjust and cruel. He is not enabling his subjects to meet their needs for food or security, let alone for independence or dignity. You think the king should be removed in favor of someone better.

There are ten nobles in the room, and only one king. The king himself is elderly and frail. In a struggle, he would never succeed in gaining personal, individual, physical supremacy over any two of you in combination, let alone over the whole room, let alone over his entire kingdom. When the king "commands" you to do a thing, though it is the king alone who speaks, you are induced to comply by something other than the king's personal ability to cause you physical harm. And something other than that is at work preventing or delaying rebellion by you and the other nobles.

You look around the room. You are not sure what the other nobles think about the idea of resistance, and it would be risky for you to ask, even in private. You know that if you make a unilateral move against the king, the others are likely to restrain you, even to kill you; unless... unless?... unless enough of the other nobles join you, because they think you are likely to succeed in your rebellion; and this in turn depends on whether enough of them think that enough of the others will join you.

This is not just about what you think, or even just about what the others think. It is about what everyone thinks everyone else thinks. This is an application of game theory. If we limit ourselves, for example, to the case of two nobles and one king, the situation resolves itself into the mathematically well-characterized "prisoner's dilemma." 17 That is: If both nobles simultaneously rebel, the revolt will succeed and both nobles will be better off. On the other hand if Noble One rebels while Noble Two remains loyal, the consequences will be extremely dire for Noble One and likely very positive for Noble Two, who, having helped to put down the revolution, can expect to be rewarded by the king. If Noble Two rebels and Noble One remains loyal this last situation is reversed. Under these circumstances-assuming impeded communication between the nobles and rational consideration by each of his or her own circumstances, plus what he or she knows about the decision facing the other-the expectation is that neither noble will rebel. The current regime will tend to represent the stable, "equilibrium" state, notwithstanding that both nobles would be better off if both rebelled. ${ }^{18}$

17 See Osborne 2004, 14-5, 26-7. The canonic prisoner's dilemma involves two prisoners arrested for a crime, held in separate cells without communication with each other. If neither prisoner informs on the other, both will be better off than if both inform on each other. If one informs on the other while the other remains quiet, the one who informs will be in the best position of all, while the one who remains quiet will be in the worst.

18 That no one rebels is, more precisely, the expected "Nash equilibrium" or steady state (Osborne 2004, 21-7). 
Similar situations have been extensively explored in economic and other contexts. A group or network "pattern" — even a non-optimal one-may be "locked in" (Arthur 1989) as a result of "synchronization effects" (Liebowitz and Margolis 1999, 91), by which individual actors following rational incentives, but taking into account what they expect others to do, thereby collectively reach outcomes less favorable to all of them. One famous ostensible instance is the "Beta/VHS" video recording technology competition of the 1980s, in which the VHS standard ultimately came to dominate even though Sony's Betamax was arguably the superior technology, simply because VHS happened to gain the earlier consumer foothold. From that "tipping point" forward it was in everyone's individual interest to join this dominant model just for the reason it was dominant, rather than purchase a superior Beta machine that would be incompatible with the rest of the world. Other examples include the Microsoft computer operating system and the QWERTY keyboard design (ibid., 23-37; 127-9).

There is in fact no end to the examples that can be identified of "locked-in" synchronous group patterns: A crowd chanting in unison at a sports event; the practice of engaging in conversation according to a certain set of grammatical conventions-even the phenomenon of a territorially defined common language.

Comparable scenarios, including particularly the common language scenario, were systematically described by the philosopher David Lewis in his 1969 book Conventions. Lewis defined a "convention" as follows:

A regularity $R$ in the behavior of members of a population $P$ when they are agents in a recurrent situation $S$ is a convention if and only if it is true that, and it is common knowledge in $P$ that, in any instance of $S$ among members of $P$,

(1) everyone conforms to R;

(2) everyone expects everyone else to conform to $R$;

(3) everyone prefers to conform to $R$ on condition that the others do. (Lewis 1969, 5-8, 58, 160-202)

That is exactly what we are talking about, but it seems better to avoid the word "convention" in the political case-on the ground it may perpetuate the idea that force is not involved.

So the group of nobles imagined above has, as a collective matter, found itself effectively "locked," in the sense we are discussing, into a pattern, by which every member of the group recognizes that every other member of the group recognizes the current ruling pattern as the controlling one, as a result of which any one member is effectively powerless to change it (barring coordination among the members, which is in the political case normally not feasible because the conspiracy itself will be treated as a capital crime if discovered). ${ }^{19}$ From this vantage the question of

19 Political science writers have been describing the same group-dynamic phenomena-not, to be sure, specifically in service of defining the terms law, sovereign, or state-since the 1960s. See Aumann, 1976, 1236; Mailath, Morris, and Postlewaite 2001. See also Baird, Gertner, and Picker 1994. Many legal writers have also referred to Lewis's idea of convention, and at least one of them, Eerik Lagerspetz, effectively captures the point being made here. See Lagerspetz 1995, 134-207, esp. 157, treating the sovereign as equivalent to the ultimate "rule of recognition" (text at notes 29-34 below) of a legal system, and the latter as a form of convention. Several others (Postema 1982; Kutz 2001), on the other hand, appear to focus on the law itself as the relevant 
"law" becomes what the locked-in pattern dictates is to be done in any given situation. This is, in its essence, an informational issue-a question of "signaling convention," in Lewis's (1969, 122-30) phrase.

In the case of a monarchy, the locked-in signaling convention is that the king's orders will be followed. If the king publicly tells one of his royal guard to arrest Noble One, in doing so the king is providing information to the entire group. Every onlooker, including the guard, expects every other onlooker to expect the commanded step to be taken; and they expect that if the guard refuses, the king will tell some other person or group to arrest both the guard and Noble One; and because the locked-in ruling pattern is that everyone expects everyone else to do what the king says, those orders will in fact be followed. The king's orders are the source of information about the details of the locked-in ruling pattern to which each individual group member is-whether she likes it or not-subject. On the other hand if any subset of people manages to coordinate their actions and successfully disregard the king, that constitutes a revolution-that is, a change to a new locked-in pattern, which is to say a change in "sovereign." 20

In a constitutional democracy like the United States the phenomenon is the same, differing only in the particulars of the source of synchronizing information to which the currently prevailing locked-in pattern directs the population. By dint of a particular set of historical events, this group-recognized information source in the US is a specific written document, the Constitution, plus those persons comprising the institutions - the presidency, Congress, and the courts-collectively recognized under the locked-in pattern as now in power under that document. ${ }^{21}$ If any one or a few individuals were to resist (in the collective, other-apprehending view of the population) that pattern, those individuals would be forcibly restrained, because every member of the population expects all the other members to expect that. That would be the case if the contravening person were a private citizen, a judge, or

convention, with judges its most relevant adherents; whereas in fact the convention of interest is political-who is in charge? - and the relevant adherents the whole of society. Others who invoke convention as identifying a possible rule of recognition include Scott Shapiro (2011, 105-10) and Andrei Marmor (2009, 155-75), though neither finds the idea completely explanatory-Shapiro $(2011,110)$ on the ground that particular individuals might have reasons other than convention for following a law. That a prisoner in the prisoner's dilemma (see note 17 above) might happen to harbor independent reasons for cooperating, however, has no effect on the equilibrium state. Schauer $(2015,81)$ also discusses some of these ideas and cites Lewis in passing. Like all the authors just discussed, however, he views the process as not inherently or completely coercive: "[T]he basic idea is that people often do engage in cooperative behavior for the common good, and do so even under circumstances in which it may seem irrational for any individual cooperator to participate" (ibid., 81; emphasis added). But the cooperative agreement "need not be, and often is not, determined by coercion in any straightforward way" (ibid., 82). The reference to voluntary "cooperative" behavior is misplaced. In the politically locked-in pattern, as in the prisoner's dilemma, adherence to the equilibrium pattern is never voluntary in the sense of there being any viable alternative.

${ }^{20}$ The same process explains why smooth monarchical succession can occur despite the temporary interstitial absence, upon the existing monarch's death, of anyone "in command" - another scenario that stymied Hart $(1961,53-4)$. The simple answer is that everyone expects everyone else to expect the crown prince to become king.

${ }^{21}$ That is, under a constitutional system the relevant "signaling agent" is, in part, something inanimate-something other than, or other than solely, a person or group of people. Lewis $(1969,129)$ noted that an inanimate object can easily serve as a group-signaling agent, pointing to the example of a traffic light. 
even the president. Had George H. W. Bush refused to leave the White House after losing the 1992 election, he would have been forcibly removed-unless, for example, enough coordinated support from the armed forces had materialized to prevent his removal, in which case we would effectively have had a revolution; as a result of which the prevailing locked-in pattern would have changed, the new one being that everyone would expect everyone else to follow the orders of Bush and the military without regard to the Constitution.

That source of information that members of the group assume the other members of the group assume is dispositive, is dispositive. If no such collective understanding exists about the content of that information, there must be a collective understanding about who is dispositively to resolve the uncertainty (such as, for example, the collective understanding that the US Supreme Court's decision in Bush v. Gore ${ }^{22}$ or in any case since Marbury v. Madison ${ }^{23}$ - would be treated as dispositive of the issues before the Court). If no locked-in collective understanding exists about that, a political crisis will have arisen.

The only remaining requisite for a "sovereign" is that the locked-in pattern be stably paramount within a territorially distinct area. This is what distinguishes the sovereign from Hart's gunman, who may have achieved a small-scale locked-in governing pattern (within the confines, for example, of a bank lobby in the midst of a robbery), which is, however, intentionally and certainly transient. ${ }^{24}$ If there is no prevailing, territorially defined, stably locked-in political ruling pattern, there is no "sovereign" - and no "law." 25 This is all a question of fact, albeit intangible fact. The existence, identity, or nonexistence of a locked-in pattern-though in every case having very tangible consequences-is not something that can itself be seen or touched but only inferred from the behavior of people.

In short, we are free with Austin to characterize law as the command of the sovereign, so long as we recognize that the definition of sovereign must be something like: That source of synchronizing signaling information identified by the prevailing locked-in political ruling pattern.

The sole difficulties for the "command theory" are presented by categories of things we may call laws but that are not enforced or enforceable. The first of these, identified by Kelsen (1961, 123), and Austin before him, involves a formal "declaration" like: "The week beginning on the third Sunday in October is hereby declared National Forest Products Week." ${ }^{26}$ Concerning such cases we can

22531 U.S. 98 (2000).

235 U.S. 137 (1803). Up to a point, to paraphrase Charles Evans Hughes $(1908,139)$, the Constitution under the US's current locked-in pattern is what the Supreme Court says it is. "Up to a point" only, however, because, on the other hand, past some factually determined boundary the Supreme Court's power is not unlimited: Beyond that boundary the group consensus would fail, because too many people would see-or, more to the point, would see too many other people as seeing - the Court as having exceeded its pattern-conferred authority.

${ }^{24}$ Priel $(2008,407)$ makes a similar point in singling out the attitude of the gunman as the distinguishing factor from law. It is not the attitude of the gunman himself, however, but of everyone involved, that matters; and the attitude in question is not, as Priel suggests, that the gunman in the legal case thinks of himself as having a "right" that the bank gunman does not, but that the expectation in the one case is only transient.

25 See Kramer 1999, 95-7, for a similar argument.

2636 U.S.C. $\S 123$. 
immediately recognize two things. First, they are trivial. No court or anyone else will be called upon to apply_-because apply has no contextual meaning-or even interpret such a declaration taken by itself. Second, and the reason for the first: These statements are not rules, where "rules" are constructions that can be rearranged in the form: "All X's must [not]/[may] $\Theta$," " $X^{\prime}$ being the rule's "protasis"- the factual predicate for a rule's application-and " $\Theta$ " the "apodosis"- the consequence the rule applies to the protasis (Schauer 1993, 23). The legal-philosophical question of interest is: When is a rule a law? To account for the declaration case we need merely revise the above formulation to say "A rule is a law if it emanates from the source of synchronizing information identified by the prevailing locked-in political ruling pattern." As to a formal declaration, you may, consistent with common usage, also call that a law if you like- that is to say, unless you think the word law should be reserved for rules-provided only the declaration has been issued by the sovereign as defined above.

A different category comprises statements issued by the sovereign that, while meeting the form of a rule, are systematically unenforced. But a rule systematically unenforced by the sovereign-and generally known to be so-is simply not in fact a "rule" or a "law" in the same sense rules meant to be enforced are. If we ask "What are actually the laws of the jurisdiction?" these should be left out, as no different from "hypothetical laws." If the objection is that such a definition of law is inconsistent with very use of a term like "unenforced law," the answer is that in that phrase the term law has a different meaning than the one with which we are centrally concerned, as is also true in the case of "rule of law."27 The above two categories are statements of the sovereign, but not "laws" in the sense with which jurisprudence is concerned.

One might again anticipate the objection the foregoing is too complex; an "ingenious," "convoluted" means of fitting law into the idea of the command of a sovereign. One answer is that the description at least defeats the claimed difference between monarchy and democracy, a distinction on which Hart's arguments turned. The more fundamental reply, however, is that if there is convolution the problem is not with the idea of coercion but with the word sovereign, which connotes a real person or group of people and is thus in the end perhaps not the best one for understanding state power in any form-a problem that long precedes Hart or even Austin. ${ }^{28}$ The solution to that problem is not to deny the significance to law of coercion, but to find a more sophisticated understanding of sovereign power, or use a different word than sovereign.

At times, to be sure, doubt exists about what a particular command means (an interpretation issue); or whether it is in fact a command of the sovereign (validity); but only where there is doubt about who or what is the sovereign is there doubt about whether "law" exists. Austin's explanation of law may be simple; it may seem

\footnotetext{
27 See text at notes $39-40$ below.

${ }^{28}$ See note 30 below. The difficulty originates not with legal philosophy but, ultimately, with political philosophy. Here, for example, is Max Weber's famous definition of a state: A "state is a human community that (successfully) claims the monopoly of the legitimate use of physical force within a given territory" (Weber [1919] 1946, 2; emphasis in original). The "monopoly of force" part is right, but major problems arise from saying that a "community" "claims" anything.
} 
obvious; it may, as a result, strike some as insufficiently gratifying; but it is the accurate explanation.

Hart perceived shadows of the above picture. He posited the existence of a "rule of recognition," which is a "secondary rule," identified by the "practice" (Hart $1961,94,263)^{29}$ or "habits" of judges, that is used for identifying those more direct rules that govern behavior and that he classed as "primary rules." For example, he said, in a simple monarchy the "rule of recognition" is that whatever the king enacts is law, meaning we look to this secondary rule in identifying what rules in the monarchy are primary rules (Hart 1961, 96). But this word habit of the judges, to identify the rule of recognition, is utterly the wrong one; ${ }^{30}$ and the problem, again, is that it connotes something elective, uncoerced. Judicial behavior is nothing of the sort. If a US Supreme Court justice began to cite the Qu'ran as legal authority in place of the Constitution, she would be (forcibly) replaced under the existing locked-in political pattern. Habits vary from one person to another, but there is always only one "legal habit system" governing the judges in any jurisdiction. The reason there is only one rule of recognition is that a stable political system implies-is-a forcibly exclusive system, controlling the "monopoly of power." The generic rule of recognition is always the same: To be law, a primary rule must emanate, directly or indirectly, ${ }^{31}$ from the currently obtaining locked-in territorial ruling pattern's information source. ${ }^{32}$

Hart's fundamental idea was that law as a "union of secondary and primary rules" is a superior explanation to law as the "command of the sovereign." Various critics, however, identified some form of the pertinent response, which is that Hart begged the question "How do we identify the rule of recognition, where there is

29 The rule of recognition resembled Kelsen's Grundnorm, or “basic norm.” Kelsen 1961, 15-6.

${ }^{30}$ Here the original fault was Austin's, whose terminology Hart adopted. Austin (1832, 199-200) had attempted a definition of sovereign as that "determinate person, or determinate aggregate of persons" to whom "the bulk of the given society are in the habit of obedience or submission." In addition to the problematic use of the word habit, we have seen that characterizing the sovereign as a determinate person or persons does not adequately capture the phenomenon in question. Austin's mistake lay in his definition of sovereign, not in including state coercion in the definition of law.

31 The "direct vs. indirect" question is another difficulty Hart $(1961,25,35-42)$ found with the command theory. But it is simply no problem to agree with Austin that actions by any official at any level of government can be traced back, through intervening commands, to the sovereign. Commands can be indirect; they can also be tacit; they are nonetheless commands.

${ }^{32}$ We here briefly mention another argument, raised by others, which because this article focuses on Hart requires deferral for full treatment to a later paper. This is the so-called "society of angels" thought experiment, associated most closely with Joseph Raz (e.g., Raz 1999, 159). Imagine, the argument goes, a society comprising people all of whom want to follow the law: These people would still need rules to coordinate their behavior. That is, even if everyone wanted to follow the law, and therefore coercive sanctions for violating it were unnecessary, there would remain a need for "law." Thus coercion is not essential to law. The problem with this argument, in brief, is that it assumes away the critical question: How do the people in the imaginary world know what the law is? Imagine, for example, there are two entities issuing contradictory edicts to the society's angels, both titled "The Law." In that case the angels will face an insuperable obstacle to their law-complying desire. A "rule of recognition" is needed, and missing. Ultimately the specific reason for this problem is that the possibility of state coercion has been artificially removed (and the thought experiment thus proves the opposite of the contention for which it is cited). 
doubt?"33 What counts, for example, if you have more than one possibility $?^{34}$ What if, in fact, there is a different purported rule of recognition on every street corner? (I might hold up a sign saying: "[1] All valid law comes from me; and [2] I say it is now the law that red means 'go'; green means 'stop.'" I will have created a union of primary and secondary rules.) There is always at most only one rule of recognition in any one place at any one time, and it is not to be understood as a function of anyone's "habit." The identity of the physically unchallenged territorial gunman-if there is one-at any given time provides the rule of recognition.

\section{The "Minimum Content of Law," International Law, and the "Rule of Law"}

Hart's inclination to view law as not "quintessentially coercive" led him-and later many others-in questionable directions. For example, Hart proposed the idea of a "minimum content" of law: certain rules that Hart thought any society will require, in some sense, of its legal system. Hart did not believe in "natural law"-the idea that there is "out there," to be discovered by moral intuition, a set of divine or otherwise pre-existing rules that would legally trump any inconsistent humanmade law. Like Bentham, Hart viewed that idea as a product of mysticism. Nonetheless Hart did assert that any society "needs" certain minimum things from its legal system. Thus the laws that prohibit crime and violence, without which there is anarchy and insecurity, form a "minimum content" - and this is a sense in which the ideas underlying natural law theory have some validity, according to Hart:

Some such phrase [as "natural necessity"] is needed [...] to convey the status of the minimum forms of protection for persons, property, and promises which are similarly indispensable features of municipal law. (Hart 1961, 193)

To put this as Hart did, as some "indispensable" "minimum content of law," on which society will somehow insist, is to mislead. It is true that only those systems that have such rules, that prevent anarchy, will be tend to be stable; will survive for long periods. But this is a matter neither of logical necessity nor of anyone's insistence, but of Darwinistic selection; and furthermore describes no definite "minimum" but rather a continuous spectrum.

A locked-in legal pattern can be more or less stable. To say it is "unstable" is to say that we can, probabilistically, expect an upheaval-a change in the pattern, a revolution-to occur sooner than later. A stable pattern is one that tends on the other hand to resist such changes for long periods. And the idea Hart was bumping against without fully apprehending is that stability in this sense partly correlates with whether the system's rules diverge too much from what most people find to be reasonable and functional. Tyrannical and capricious dictatorships, or any systems that do not guarantee personal security for too many citizens, tend to bring themselves down, to be outlasted by more rational systems, because they are more

\footnotetext{
${ }^{33}$ What rule is used to identify the rule of recognition? A process of perpetual abstraction, of infinite regression, appears required. See, e.g. Raz 2009, 55.

${ }^{34}$ See Schauer 2015, chap. 6, for extended discussion of jurisprudential issues raised by competing claims to sovereignty.
} 
prone to motivating sufficient numbers of people to risk everything to upset the existing pattern. ${ }^{35}$ This observed tendency does not in any sense identify a requisite, a "minimum content," for something's being a legal system. It is instead like the situation of a rock rolling down a mountain. The rock may be stopped in its progress by encountering a ravine or outcrop. The deeper the ravine, the more "stable" the position; that is, the more external disruption necessary to dislodge the rock. ${ }^{36}$ The most stable position is at the bottom of a valley:

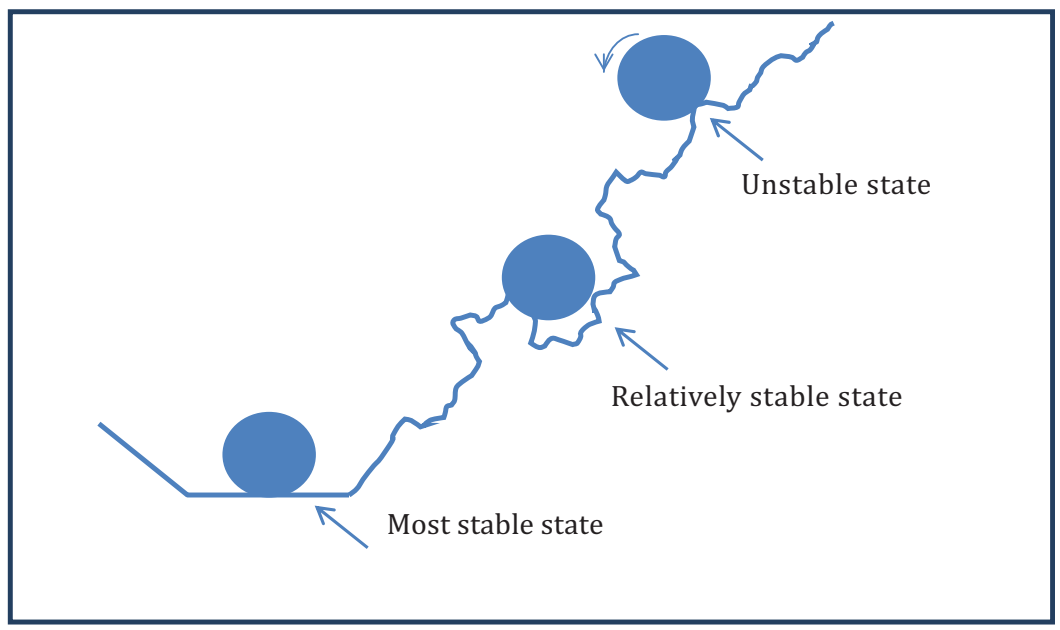

Pure anarchy-with no enforced rules whatsoever-is the maximally unstable situation; analogous to the rock's being in freefall. Such a situation will change immediately; neither rock nor society can continue to occupy its current position for more than an instant. We might hypothesize, by contrast, that a perfectly constructed democracy could be expected to occupy the most stable position. ${ }^{37}$ Even that would not be to suggest that a perfect democracy could not be disrupted; moved back to a position of relative instability by some event or catalyst (as, in the case of the rock, by an earthquake, to a higher trough); but only that that is the position to which systems will, probabilistically and over the very long term, tend.

Hart's treatment of international law, to which he devoted a long chapter of The Concept of Law, was equally dubious. He noted that international law is characterized by lack of an enforcement mechanism, a fact that has caused many observers to question whether international law is really "law." Hart explained, however, that enforcement is missing, not because international law is not "law," but because enforcement isn't actually needed in that context:

35 A recent example is the "Arab Spring," proximately caused not by any apparent mass commitment to an abstract democratic ideal, but by rampant corruption and irrational ruleapplication, which at some point sufficiently outraged a sufficient number of people and touched off revolution (Fisher 2011).

36 We are using stability in the same sense it is used in chemistry or physics.

37 This would be an empirical thesis, which it will require more history in order to test. 
[A]ggression between states is very unlike that between individuals. The use of violence between states must be public, and though there is no international police force, there can be very little certainty that it will remain a matter between aggressor and victim, as a murder or theft, in the absence of a police force, might [...]. Hence the organization and use of sanctions may involve fearful risks and the threat of them add little to the natural deterrents. Against this very different background of fact, international law has developed in a form different from that of municipal law. (Hart 1961, 219)

This is deeply problematic. In sum: Hart was continuing to contest the idea that forcible sanction is necessary to the concept of law. One argument in favor of that necessity is that international law has struck many writers as not "law" in the same way that a domestic statute is law-thereby revealing the implicit boundaries for them of the word-and the reason is that there is no enforcement mechanism. Hart's reply was effectively that international law has no enforcement mechanism because there is less need for enforcement in that sphere. By this he can only be understood as suggesting that rules falling under the heading "international law" are seldom breached, due to "natural deterrents." Had the case been otherwise, it seems, we would have found as a planet that there was, to the contrary, some need for an international law enforcement regime, and we would have instituted one.

The soundness of Hart's factual predicate does not survive the opening of a newspaper; the viability of his argument does not survive its hearing. When Napoleon invaded Spain; when Hitler attacked Czechoslovakia; when the United States tortured alleged Al Qaeda militants - all notoriously in violation of what everyone else accepted as "international law" — the lack of response was not the result of the world's having decided enforcement was unneeded. It was the result of there being no one to do the enforcing; and it is this specific distinction with domestic law that leads people to wonder whether "international law" is really an apt phrase. International law is "sort of" law exactly to the extent and for the reason that there is "sort of" enforcement, because there is no "sovereign." The word law is effectively used here in a different sense, as appears from the fact that replacing the phrase "international law" with "multilateral convention" produces no consequential change in implication. ${ }^{38}$

Yet another use of the word law that confounded Hart, among others, is found in the phrase "rule of law." As in the phrase "international law," the word is used here in a particular sense; given a particular meaning, distinct from other meanings. When we say a system is a "government of laws, not of men," 39 the idea conveyed is that the collectively recognized ultimate source of signaling information under the prevailing locked-in political pattern is a specific set of words, to which even the highest-ranking person is collectively regarded as subject, as in the United States, rather than simply being the views of that person him- or herself. ${ }^{40}$ Actual people are involved in applying the laws of a government of either character; the

${ }^{38}$ Whether or not "international law" is "law" is not, however, the ultimate point of interest here, which is that the fact people have so frequently questioned whether international law is really "law" is evidence that the word, as it is used, is inextricably linked with the idea of monopolized coercive sanction.

${ }^{39}$ Massachusetts Constitution, Part the First, Art. XXX (1780).

${ }^{40}$ See note 21, above, and accompanying text. Contrast Sunstein 1995, 955, 968, where the author, drawing from work of Lon Fuller and Joseph Raz, lays down fully seven-somewhat duplicative-characteristics of "rule of law," including even "(6) no rapid changes in the content of law; and (7) no contradictions or inconsistency in the law." The gravamen of the concept is in 
difference arises from the nature of the actual, ultimate, collectively compelled source of command information for those people.

\section{The Internal Point of View}

As a part of his critique Hart emphasized what was, in his view, the defining tendency of officials and other participants in a legal system to internalize an "obligation" to follow law-that is, law qua law; law for its own sake. The notion of an "internal point of view" (Hart 1961, 82-99) uniquely identified with law has led directly to the work of many other writers. Though space limitations require that we defer full treatment of this subject, some immediate implications can be outlined.

First, Schauer has shown the assumption is questionable that people generally feel any such obligation. It is not trivial, as Schauer demonstrates, to disentangle sanction-based from non-sanction-based reasons for following a law, but rigorous attempts to do so empirically suggest that people have little tendency to obey law just because it is law (Schauer 2015, 61-7).

Second (and the basic point to be made here): If the definitional argument in this paper is right, then the discussion of internal obligation has been badly structured. We should take law as the command of the sovereign and then ask whether, in that case, there generally exists a moral reason to follow law qua law; or, alternatively, whether people empirically do feel a reason to follow law qua law. It simply makes no sense-gets things backwards, sows confusion-to put the threshold question as: To what extent is the moral obligation to obey law a part of the ab initio definition of law, given that coercion is not such a part? and then to proceed from there. ${ }^{41}$

None of the foregoing should be thought cynical. The goal is accuracy, and accuracy is probably helpful to achieving progressive goals in the world. ${ }^{42}$ The assertion a coercion-centered understanding of law is cynical brings to mind criticisms over the years of Oliver Wendell Holmes, whom many writers have found, it sometimes seems, too clear of expression for their comfort or taste. One of these was Hart. In his famous "bad man" quotation, Holmes had said that

If you want to know the law and nothing else, you must look at it as a bad man, who cares only for the material consequences which such knowledge enables him to predict, not as a good one, who finds his reasons for conduct, whether inside the law or outside of it, in the vaguer sanctions of conscience. (Holmes 1897, 459)

\section{Hart's response?}

fact subsumed entirely within requirement (3): "a measure of conformity between law in the books and law in the world."

${ }^{41}$ A characteristic example of this post-Hart approach was recently provided by Matthew Kramer $(2013,105)$ : "As has been evident at least since the time of Hart's famous critique of Austin, the latter thinker's jurisprudential ideas are vitiated by their disregard of the normativity of laws' contents and effects." If we take as given that law has normative quality, just by virtue of its being law, this statement makes sense. But as noted there is doubt about that precondition as an empirical matter, and we have been given - by Hart, Kramer, or anyone else-no non-empirical reason to think it valid. Schauer $(2015,35)$ summarizes the confusion as well as it could be done: "The puzzle of legal normativity is not the puzzle of trying to explain why there is a nonmoral and nonlegal wrongness to being legally wrong. It is the puzzle of why anyone would think there was in the first place."

42 See Schauer 2015, 11-5, 180 n. 22 (referring to Bentham's goals as a "radical reformer"). 
Why should not law be equally if not more concerned with the "puzzled man" or "ignorant man" who is willing to do what is required, if only he can be told what it is? (Hart 1961, 40)

Hart here seems more or less completely to have missed Holmes's point, which was that, whether you are a good man or a puzzled man or a tall man, your route to finding out "what the law is" is to look at the question as though you were a bad man who wished to get away with the maximum you could get away with. That definition of legal boundary applies to everyone: There is not a different definition of "what law is" depending on who asks the question, nor did Hart argue there is. And saying law is to be determined by reference to a bad man did not make Holmes a bad man, or a cynical man.

\section{Conclusion}

In the end it is hard to understand the acclaim with which Professor Hart's work was received. The irony is that Hart was a scholar of Jeremy Bentham (see Lacey 2004, 156, 290), yet Hart's own ultimate long-term place in jurisprudential history may be destined - as the celebrated, authoritative voice of a conventional understanding that is completely wrong-to occupy a position closer to that of William Blackstone, the famous object of Bentham's vitriol.

Harder to understand, however, is the iron hold Hart's theory of the irrelevance of coercion has exercised for so many years on the collective understanding of the world's legal thinkers. Mistaken as it is, Hart's postulate has ramified into countless, extended, and at least equally questionable speculations, across the whole of the reach of legal academia. Assessment of these further consequences must await another occasion.

University of Michigan Law School 625 South State Street Ann Arbor, Michigan 48109-1215

USA

E-mail: astumpff@umich.edu

\section{References}

Anderson, S. A. 2010. The Enforcement Approach to Coercion. Journal of Ethics \& Social Philosophy 5: 1-31.

Arthur, W. B. 1989. Competing Technologies, Increasing Returns, and Lock-In by Historical Events. Economic Journal 99: 116-31.

Aumann, R. J. 1976. Agreeing to Disagree. The Annals of Statistics 4: 1236-9.

Austin, J. 1885. Lectures on Jurisprudence. London: John Murray. (5th ed. R. Campbell)(1st ed. 1863.)

Austin, J. 1995. The Province of Jurisprudence Determined. Ed. W. Rumble. Cambridge: Cambridge University Press. (1st ed. 1832.)

Baird, D. G., R. H. Gertner, and R. C. Picker. 1994. Game Theory and the Law. Cambridge, MA: Harvard University Press.

Bentham, J. 1945. The Limits of Jurisprudence Defined: Being Part Two of An Introduction to the Principles of Morals and Legislation. Now First Printed from the Author's Manuscript, with an Introduction by Charles Warren Everett. New York: Columbia University Press. 
Bentham, J. 1977. A Comment on the Commentaries. In The Collected Works of Jeremy Bentham: A Comment on the Commentaries and A Fragment on Government. Ed. J. H. Burns and H. L. A. Hart, 3-389. Oxford: Oxford University Press. (1st ed. pub. anon. 1776.)

Christie, G. C. 1968. The Model of Principles. Duke Law Journal 1968: 649-69.

Dworkin, R. 1996. Freedom's Law: The Moral Reading of the American Constitution. Cambridge, MA: Harvard University Press.

Edmundson, W. A. 1995. Is Law Coercive? Legal Theory 1: 81-111.

Fisher, M. 2011. In Tunisia, Act of One Fruit Vendor Unleashes Wave of Revolution through Arab World. Washington Post, March 26.

Hägerström, A. 1953. Inquiries into the Nature of Law and Morals. Ed. K. Olivecrona. Stockholm: Almqvist \& Wiksell. (1st ed. in Swedish 1917.)

Hart, H. L. A. 1957. Positivism and the Separation of Law and Morals. Harvard Law Review 71: 593-629.

Hart, H. L. A. 1961. The Concept of Law. Oxford: Oxford University Press.

Holmes, O. W. 1897. The Path of the Law. Harvard Law Review 10: 457-78.

Hughes, C. E. 1908. Speech before the Elmira Chamber of Commerce, May 3, 1907. In Addresses and Papers of Charles Evans Hughes, 133-46. New York and London: Putnam.

Hughes, R. C. 2013. Law and the Entitlement to Coerce. In Philosophical Foundations of the Nature of Law. Ed. W. Waluchow and S. Sciaraffa. Oxford: Oxford University Press.

Kelsen, H. 1961. General Theory of Law and State. Cambridge, MA: Harvard University Press. (1st ed. in German 1934.)

Kramer, M. H. 1999. In Defense of Legal Positivism: Law without Trimmings. Oxford: Oxford University Press.

Kramer, M. H. 2013. John Austin on Punishment. In vol. 2 of Oxford Studies in Philosophy of Law. Ed. L. Green and B. Leiter, 103-21. Oxford: Oxford University Press.

Kutz, C. 2001. The Judicial Community. Philosophical Issues 11: 442-69.

Lacey, N. 2004. The Nightmare and the Noble Dream: A Life of H. L. A. Hart. Oxford: Oxford University Press.

Lagerspetz, E. 1995. The Opposite Mirrors: An Essay on the Conventionalist Theory of Institutions. Dordrecht: Kluwer.

Lamond, G. 2001. Coercion and the Nature of Law. Legal Theory 7: 35-57.

Lewis, D. 1969. Conventions. Cambridge, MA: Harvard University Press.

Liebowitz, S. J., and S. E. Margolis. 1999. Winners, Losers E Microsoft. Oakland, CA: The Independent Institute.

Mailath, G. J., S. Morris, and A. Postlewaite. 2001. Laws and Authority. Unpublished MS, available at https://www.princeton.edu/ smorris/pdfs/laws\&authority.pdf

Marmor, A. 2009. Social Conventions: From Language to Law. Princeton, NJ: Princeton University Press.

Nozick, R. 1969. Coercion. In Philosophy, Science, and Method: Essays in Honor of Ernest Nagel. Ed. S. Morgenbesser, P. Suppes, and M. White, 440-72. New York: St. Martin's.

Osborne, A. J. 2004. An Introduction to Game Theory. New York: Oxford University Press.

Postema, G. 1982. Coordination and Convention at the Foundation of Law. Journal of Legal Studies 11: 165-203.

Postema, G. 2001. Law as Command: The Model of Command in Modern Jurisprudence. Philosophical Issues 11: 470-501.

Pound, R. 1945. Book Review. Texas Law Review 23: 411-18.

Priel, D. 2008. Sanction and Obligation in Hart's Theory of Law. Ratio Juris 21(3): 404-11. 
Raz, J. 1999. Practical Reason and Norms. Oxford: Oxford University Press. (1st ed. 1975.) Raz, J. 2009. The Authority of Law. Oxford: Oxford University Press. (1st ed. 1979.) Ripstein, A. 2004. Authority and Coercion. Philosophy \& Public Affairs 32: 2-35.

Schauer, F. 1993. Playing by the Rules: A Philosophical Examination of Rule-Based Decision-Making in Law and in Life. Oxford: Oxford University Press.

Schauer, F. 2010a. Was Austin Right After All? On the Role of Sanctions in a Theory of Law. Ratio Juris 23(1): 1-21.

Schauer, F. 2010b. The Best Laid Plans. Yale Law Journal 120: 586-621.

Schauer, F. 2015. The Force of Law. Cambridge, MA: Harvard University Press.

Shapiro, S. J. 2011. Legality. Cambridge: Harvard University Press.

Sunstein, C. R. 1995. Problems with Rules. California Law Review 83: 953-1026.

Weber, M. 1946. Politics as a Vocation. Ed. H. H. Gerth and C. W. Mills. Philadelphia: Fortress. (Speech originally delivered in German 1919.)

Yankah, E. N. 2008. The Force of Law: The Role of Coercion in Legal Norms. Richmond Law Review 42: 1195-255. 